\title{
STANDING COMMISSION OF THE INTERNATIONAL RED CROSS
}

Meeting on 21 April 1969 in Geneva, the Standing Commission made plans for the 21 st International Conference of the Red Cross, which will take place in Istanbul from 6 to 13 September 1969 and which will be preceded by a meeting of the Board of Governors of the League. Representatives of the Turkish Red Crescent Society were also present.

On the Conference agenda is the study of problems in the fields of international humanitarian law, relief to the civilian populations in armed conflicts and the extension and development of Red Cross activities in time of peace.

The Conference is the highest deliberative authority of the International Red Cross. It brings together representatives of the ICRC, the League, the 111 internationally recognised Red Cross, Red Crescent and Red Lion and Sun Societies, and the States parties to the Geneva Conventions. Observers from a large number of international and national governmental and non-governmental organisations also attend.

The Standing Commission has as Chairman Angela, Countess of Limerick (Great Britain), and is composed as follows: Vice-Chairman Dr. Hans von Lauda (Austria); General James F. Collins (USA); Prof. Dr. G. A. Miterev (USSR); Sir Geoffrey Newman-Morris (Australia); Mr. Jacques Freymond, ICRC Vice-President; Mr. Jean Pictet, ICRC Member and Director-General, and two representatives of the League, Mr. José Barroso, Chairman of the Board of Governors, and Mrs. A. F. Issa-el-Khoury (Lebanon). 